\title{
The impact of stroke on the quality of life of children and adolescents
}

\author{
O impacto do acidente vascular cerebral na qualidade de vida de crianças e adolescentes \\ El impacto del ataque cerebrovascular en la cualidad de vida de niños y adolescentes \\ Laís Rodrigues Gerzson', Josiane Ranzan², Carla Skilhan de Almeida³, Rudimar dos Santos Riesgo',2
}

\begin{abstract}
The aim of this study was to evaluate the quality of life (QoL) of children/adolescents with a diagnosis of stroke (CVA) in the eyes of the person responsible and the children / adolescents themselves compared to a control group. 78 subjects were divided into: Group of children / adolescents who had a history of stroke (GAVC, $n=39$ ) and a group of healthy children/adolescents as Control (CG, $n=$ 39) matched by gender and age. A semi-structured interview was used to describe the sociodemographic aspects and the Pediatric Quality of Life Inventory (PedsQL ${ }^{\mathrm{TM}}$ 4.0) to evaluate the QoL of the subjects in their development. The median age of the diagnosis of stroke was 7 months, with the majority presenting ischemic stroke (71.8\%) and hemiparesis.According to those responsible for the GAVC, the Functional Capacity of their children was significantly different, presenting inferiority in relation to the CG. Also, for those in charge, the father's educational variable maintained a significant positive effect on the emotional aspects of the child, and the variable age of the child/adolescent and stroke time> 29 days of life had a negative effect on the school aspects. As for the children / adolescents, the variable age that entered school and gender had a significant negative effect on the outcome of school aspects in relation to the CG. We conclude that the view of those responsible differs from the child/adolescent's view of their functional capacity; the father's schooling positively influenced the emotional aspects of the child and the children feel a loss in school performance, especially the boys.
\end{abstract}

Keywords I Stroke; Child; Adolescent; Quality of Life.
RESUMO I O objetivo deste estudo foi avaliar a qualidade de vida (QV) de crianças/adolescentes com diagnóstico de acidente vascular cerebral (AVC) segundo as percepções do responsável e das próprias crianças/ adolescentes comparados com um grupo controle (GC). Participaram 78 sujeitos divididos em: Grupo de crianças/ adolescentes que tiveram histórico de AVC (GAVC, n=39) e um Grupo de crianças/adolescentes saudáveis como Controle (GC, n=39), sendo pareados por sexo e idade. Utilizou-se de entrevista semiestruturada para descrever os aspectos sociodemográficos e do instrumento Pediatric Quality of Life Inventory (PedsQL'T 4.0) para avaliar a QV dos sujeitos no seu desenvolvimento. A mediana de idade do diagnóstico de AVC do GAVC foi sete meses, sendo que a maioria apresentou AVC isquêmico (71,8\%) e hemiparesia. De acordo com os responsáveis do GAVC, a Capacidade Funcional dos seus filhos foi significativamente diferente, apresentando inferioridade em relação ao GC. Para os responsáveis também a variável escolaridade do pai manteve efeito positivo significativo nos aspectos emocionais da criança, e a variável idade da criança/adolescente e tempo do AVC > 29 dias de vida apresentou efeito negativo nos aspectos escolares. Já para as crianças/adolescentes, a variável idade em que entrou na escola e gênero apresentou efeito significativo negativo no desfecho de aspectos escolares em relação ao GC. Concluímos que a percepção dos responsáveis difere da percepção da criança/adolescente em relação à capacidade funcional desta; a escolaridade do pai

Neuropediatrics Unit and Primary Healthcare Unit Santa Cecília of Hospital de Clínicas de Porto Alegre - Porto Alegre (RS), Brazil. 'Graduate Program in Health of the Child and Adolescent, Universidade Federal do Rio Grande do Sul (UFRGS) - Porto Alegre (RS), Brazil.

${ }^{2}$ Neuropediatrics Unit, Hospital de Clínicas de Porto Alegre, Universidade Federal do Rio Grande do Sul (UFRGS) - Porto Alegre (RS), Brazil.

${ }^{3}$ Physical Therapist, Ph.D. in Human Movement Science, professor of the Physical Therapy at Universidade Federal do Rio Grande do Sul (UFRGS) - Porto Alegre (RS), Brazil. 
influenciou positivamente nos aspectos emocionais da criança, e as crianças sentem-se com um prejuízo no desempenho escolar, principalmente os meninos.

Descritores | Acidente Vascular Cerebral; Criança; Adolescente; Qualidade de Vida.

RESUMEN | El objetivo de este estudio ha sido evaluar la cualidad de vida (CV) de niños/adolescentes con diagnóstico de ataque cerebrovascular (ACV), según las percepciones del responsable y de los propios niños/adolescentes comparados con un grupo control (GC). Han participado 78 sujetos divididos en: Grupo de niños/adolescentes que han tenido histórico de ACV (GACV, n=39) y un Grupo de niños/adolescentes saludables como Control (GC, n=39), siendo pareados por sexo y edad. Se ha utilizado de encuesta semiestructurada para describir los aspectos sociodemográficos y del instrumento Pediatric Quality of Life Inventory (PedsQL ${ }^{\mathrm{TM}}$ 4.0) para evaluar la CV de los sujetos en su desarrollo. El promedio de edad del diagnóstico de ACV del GACV ha sido siete meses, siendo que la gran parte ha presentado ACV isquémico (el 71,8\%) y hemiparesia. De acuerdo con los responsables del GACV, Ia Capacidad Funcional de sus hijos ha sido significativamente, distinta, presentando inferioridad en relación al GC. Para los responsables también la variable escolaridad del padre ha mantenido el efecto positivo significativo en los aspectos emocionales del niño, y la variable edad del niño/adolescente y tiempo del ACV > 29 días de vida ha presentado el efecto negativo en los aspectos escolares. Ya para los niños/adolescentes, la variable edad en que ha ingresado a la escuela y el género ha presentado efecto significativo negativo en el desfecho de aspectos escolares en relación al GC. Hemos concluido que la percepción de los responsables difiere de la percepción del niño/adolescente en relación a la capacidad funcional de esta; la escolaridad del padre ha influenciado positivamente en los aspectos emocionales del niño, y los niños se sienten con un perjuicio en el desempeño escolar, principalmente los niños.

Palabras clave | Accidente Cerebrovascular; Niño; Adolescente; Calidad de Vida.

\section{INTRODUCTION}

The cerebral vascular accident (CVA) or stroke is characterized by a sudden occlusion or rupture of cerebral vessels that causes a focal brain injury and neurologic deficits ${ }^{1}$. The risk factors for pediatric stroke are diverse and different from the cases of strokes in adults $^{2}$. Pediatric stroke is among the ten leading causes of death in the pediatric population ${ }^{3}$. Its annual incidence varies from 2 to 13 per 100,000 children/year ${ }^{4}$.

According to the period of life in which the cerebrovascular event occurred, the pediatric stroke can also be divided into: neonatal CVA or child CVA. Neonatal CVA is defined as an acute focal neurologic deficit, with duration greater than 24 hours, and occurs in the prenatal period (can also be called fetal CVA), perinatal, or before the first 28 days after birth ${ }^{5}$. In the case of child CVA, this cerebrovascular event occurs between the ages of 29 days and 18 years ${ }^{5}$.

The hospitalization costs of children who suffered from a stroke are high, and the situation is exacerbated by the extensive duration of post-stroke deficiencies in childhood, which may last for decades ${ }^{6,7}$. In other words, the children/adolescents can present sequelae that modify their functional skills, such as running, practicing sports, climbing stairs, being free to come and go, dressing, feeding, and cleaning themselves. Functional capacity as dictated by the World Health Organization $^{8}$ states that the International Classification of Functioning, Disability and Health (ICF) includes the explanatory model of functionality and inability so as to belong to the health conditions, disseminating a conceptual multifactorial proposal that include biopsychosocial factors. The ICF is a useful tool to identify the environmental and personal factors that favor their activities and, consequently, their quality of life (QoL) $)^{9}$.

Measuring QoL can play a vital role in assessing the health needs of individuals, their role in the community, having fundamental implications for health care, resource allocation, planning, and public policies formulation ${ }^{10}$. However, it has been observed that the measurement of QoL may have different points of views. For example, the QoL perceived by children/adolescents with neurological implications is different from the QoL perceived by their guardians. In a research by Ghotra et al. ${ }^{11}$, the guardians reported that the emotional sphere was the most affected, while the children noticed more the physical aspect. In another research ${ }^{12}$, guardians and children indicated that school and psychosocial functioning were hindered the most. These findings highlight the importance of evaluating the QoL of pediatric patients, 
and also take into account the perspectives of the child/ adolescent's guardians.

Analyzing it biopsychologically, the guardians' perspectives influence directly on the child/adolescent's perspectives regarding the future of this society. For instance, a child believes to be capable of doing something, but his/her parents discourage it. This influence can be positive or negative. Therefore, it must be balanced to achieve a good biopsychosocial development. These points of views should be approximated to become facilitator, and not limiting, perspectives.

Therefore, the aim of this study was to evaluate the quality of life (QoL) of children/adolescents with a diagnosis of stroke (CVA) in the perception of their guardians and the children/adolescents themselves, compared to the perceptions of guardians and children/ adolescents from a control group (CG).

\section{METHODOLOGY}

\section{Design and participants}

This is a cross-sectional study with a control group. Seventy-eight children and their guardians participated, divided into: Group of children/adolescents with a history of stroke (CVAG, $n=39$ ) and a control group of children and adolescents $(\mathrm{CG}, \mathrm{n}=39)$, matched by sex and age, recruited at the Neuropediatrics Unit of the Hospital de Clínicas de Porto Alegre (HCPA). The CG was recruited at the Basic Health Unit in the same area of the hospital. Sample size was calculated by the WinPepi software, version 11.43 , considering a significance level of $5 \%$, power of $90 \%$, a difference of at least 12 points between the total score averages of the PedsQL ${ }^{\mathrm{TM}} 4.0$ from the two groups, standard deviation of 16.73 for the case group and 7.35 for the control group $^{13}$, and an increase of $10 \%$ for possible losses and refusals, thus coming to a sample of 52 individuals, with 26 children in each group.

The diagnosis of stroke was performed by a neuropediatric physician before this study was carried out, as well as by complementary examinations (MRI, CT scan, among others). This research was approved by the Ethics and Research Committee of the Hospital de Clínicas de Porto Alegre (CAAE 44157415.0.0000.5327). The guardians signed an informed consent form. Individuals who presented any suspicion of other neurological diseases (except for the stroke sequelae) or other clinical conditions involving motor development or intellectual delay were excluded from the study.

\section{Instruments and collection procedures}

The data collection team was composed by one physical therapy professional and two neuropediatric physicians. They were trained two weeks before the collection began to standardize the evaluation.

The identification data of the CVAG and CG were collected through the medical records of the Neuropediatrics Unit of the HCPA and from the Basic Health Unit Santa Cecilia, respectively, to analyze if the research criteria were met. After these procedures, the interviews were carried out in the two locations mentioned above. A semi-structured interview was carried out with the guardians for them to describe the sociodemographic aspects.

The Pediatric Quality of Life Inventory (PedsQL ${ }^{\mathrm{TM}}$ 4.0) instrument was used to evaluate the QoL of the child/ adolescent regarding the different aspects of development, in the perception of the guardians when the child was aged under 4 years, and in the perception of both guardians and the child/adolescent from the age of 5 years.

The Peds $\mathrm{QL}^{\mathrm{TM}} 4.0$ is a generic instrument consisting of 23 multidimensional items encompassing physical (eight items), emotional (five items), social (five items), and school-related (five items) aspects. This instrument was selected since it is aligned with the ICF, which is based on the biopsychosocial model, in which the function is directly related to the quality of life of the individual who has a disability and the interrelation between the personal and environmental context ${ }^{14}$.

The guardians' blocks are parallel to the children/ adolescents' blocks, with the aim of evaluating the guardians' perceptions of the children/adolescents' quality of life. The items from the blocks are basically identical, differing only regarding language adequacy, either in the first or third person ${ }^{15}$.

During the answering of PedsQL ${ }^{\mathrm{TM}} 4.0$, the researcher asked how much of each problem the individual has had in the last month. In the children/adolescents' accounts, ranging in age from 8 to 18 years, and in those of their caretakers, a 5-point response scale was used ( $0=$ it is never a problem; 1 = it is almost never a problem; $2=$ sometimes it is a problem; $3=$ it is often a problem, and $4=i$ is almost always a problem). For children aged from five to seven years, the scale was simplified to three points ( 1 = it is never a problem; 2 = sometimes it is a problem; 
$3=$ it is often a problem), and each was response linked to a visual analog scale with faces: cheerful, neutral, and sad, respectively. The guardians' account also includes the ages from 2 to 4 years, which does not occur in the account of the children aged under 5 years, which includes only 3 items to the school aspect ${ }^{16}$.

The items are reverse scores and linearly transformed to a scale from 0 to $100(0=100,1=75,2=50,3=25,4=0)$. Thus, high scores indicated better quality of life. The scale scores are analyzed by the sum of the items divided by the number of items answered (taking into account missing data). If over $50 \%$ of the items in the scale are not answered, it should not be computed ${ }^{17}$.

\section{Data analysis}

Data description was carried out using absolute (n) and relative (\%) frequencies for qualitative variables, and by average and standard deviation for quantitative variables in case of symmetrical distribution. In cases with asymmetric distribution, median and interquartile range were used. To compare the averages of the quality of life scores, we used Student's $t$ test for independent samples (when two groups were considered, such as sex) or the one-way Analysis of Variance (Anova), complemented by Tukey test (when three or more groups were considered, such as type of CVA). For the control of confounder factors, the Analysis of Covariance (Ancova) and linear multivariate regression were used. The criterion for entry of the variable in the multivariate model was to present a $\mathrm{p}$-value $<0.20$ in the bivariate analysis. Effect size was calculated using the standardized mean difference between the groups (Cohen's $\mathrm{d}$ ). The following criteria for classification were used: below 0.5 , weak effect; from 0.5 to 0.8 , moderate effect; above 0.8 , great effect. For all the analysis, we used the software Statistical Package for the Social Sciences (SPSS) version 21.0, considering a significance level of 5\%.

\section{RESULTS}

We selected to participate in this study 39 children diagnosed with stroke from the database of the Neuropediatrics Unit of HCPA. For the CG, we invited 39 children from the Basic Health Unit Santa Cecília, being paired by sex and age.

The results of the sample characterization are shown in Table 1. A significant difference was observed between the groups both in the mother's education level and the father's education level $(\mathrm{p}<0.001)$. The type of school, especially the private and municipal institutions, presented a significant difference $(\mathrm{p}=0.001)$, as well as the family income $(p=0.016)$, being higher in the CG. The remaining variables of Table 1 did not present a significant difference.

Table 1. Sample characterization

\begin{tabular}{|c|c|c|c|}
\hline Variables & CVA $(n=39)$ & Control $(n=39)$ & p \\
\hline Mother's age (years) & $37.6 \pm 9.5$ & $38.9 \pm 8.9$ & 0.531 \\
\hline Father's age (years) & $40.5 \pm 11.9$ & $40.2 \pm 11.7$ & 0.904 \\
\hline Mother's education level (years) & $7.9 \pm 3.1$ & $10.9 \pm 3.9$ & $<0.001$ \\
\hline Father's education level (years) & $7.2 \pm 2.8$ & $10.2 \pm 3.4$ & $<0.001$ \\
\hline White mother & $26(66.7)$ & $34(87.2)$ & 0.060 \\
\hline White father & $26(76.5)$ & $29(78.4)$ & 1.000 \\
\hline White child & $33(84.6)$ & $37(94.9)$ & 0.263 \\
\hline Child's age (years) & $10.3 \pm 4.9$ & $10.5 \pm 5.0$ & 0.873 \\
\hline Female child & $21(53.8)$ & $21(53.8)$ & 1.000 \\
\hline Attends school & $33(84.6)$ & 35 (89.7) & 0.735 \\
\hline Type of school & & & 0.001 \\
\hline Private & $1(3.0)$ & $10(28.6)$ & \\
\hline State & $18(54.5)$ & $21(60.0)$ & \\
\hline Municipal & $14(42.4)$ & $3(8.6)$ & \\
\hline Federal & $0(0.0)$ & $1(2.9)$ & \\
\hline Age when first attending school (months) & $56.2 \pm 25.3$ & $45.8 \pm 25.5$ & 0.092 \\
\hline
\end{tabular}




\begin{tabular}{|c|c|c|c|}
\hline Variables & CVA $(n=39)$ & Control $(n=39)$ & $p$ \\
\hline Child's education level (years) & $5.4 \pm 3.2$ & $5.5 \pm 3.9$ & 0.916 \\
\hline Grade retention rates at school & $15(44.1)$ & $10(28.6)$ & 0.275 \\
\hline Participates in extracurricular activities & $10(25.6)$ & $13(33.3)$ & 0.619 \\
\hline Parents live together & $22(56.4)$ & $25(64.1)$ & 0.644 \\
\hline Income (Brazilian reais) & $1182(788-2364)$ & $1576(1100-3500)$ & 0.016 \\
\hline Planned pregnancy & $15(38.5)$ & $19(48.7)$ & 0.493 \\
\hline Complications during pregnancy & $31(79.5)$ & $28(71.8)$ & 0.598 \\
\hline Vaginal type of childbirth & $23(59.0)$ & $19(48.7)$ & 0.496 \\
\hline GA (weeks) & $36.8 \pm 3.5$ & $38.0 \pm 2.0$ & 0.076 \\
\hline
\end{tabular}

CVA: cerebrovascular accident (stroke); n: number; GA: gestational age.

The median of age (in months) in the diagnosis of the CVAG was seven months, prevailing the female sex (53.8\%). The majority of children presented stroke of the ischemic type (71.8\%). The main affected vascular territory in the sample was the middle cerebral artery (53.8\%). The majority of children/adolescents presented time of the CVA > 29 days (56.4\%). In the neurological examination, it was found that the greatest prevalence was of right hemiparesis (Table 2).

According to the guardians' PedsQL ${ }^{\mathrm{TM}} 4.0$, it was possible to identify a significant difference and a large effect size in the score of functional capacity, i.e., the guardians from the CVAG understood that their children had a much lower capacity than that those from the $\mathrm{CG}$, as they presented an inferior score, even after the adjustment by confounder factors. The other variables showed no significant differences.

In the design of the children/adolescents' PedsQL ${ }^{\mathrm{TM}}$ 4.0 , none of the items presented a statistically significant after the adjustment by confounder factors (Table 3).

Through the multivariate linear regression analysis, we found that the father's education level in the PedsQL ${ }^{\mathrm{TM}}$ 4.0 answered by the guardians had a significant positive effect on the emotional aspects after adjustment, i.e., the guardians understood that their education level was important to the emotional aspects of the child/ adolescent with stroke sequelae when compared to the CG.

Regarding the social aspects, no variable maintained a significant effect after the adjustment by the multivariate model, possibly due to the small number of children/ adolescents in the CVA group, while the variables age of the child/adolescent regarding education level and time of CVA > 29 days of life in the guardians' PedsQL ${ }^{\text {TM }} 4.0$ showed a negative effect, i.e., the parents understand what their children are harmed for first attending school late or because they are in school years that do not match their chronological age due to hospitalizations, grade retention (Table 1), or any other limitation that the children/adolescents have at the time, and understand that, the older the children have the CVA, the worse it will be.

Table 2. Profile of patients with CVA

\begin{tabular}{|c|c|}
\hline Variables & $\mathrm{n}=39$ \\
\hline CVA diagnosis (months) - md (P25 - P75) & $7(4-48)$ \\
\hline \multicolumn{2}{|l|}{ Child's sex } \\
\hline Female & $21(53.8)$ \\
\hline Male & $18(46.2)$ \\
\hline \multicolumn{2}{|l|}{ CVA type - n (\%) } \\
\hline Ischemic & $28(71.8)$ \\
\hline Hemorrhagic & $8(20.5)$ \\
\hline Venous sinus thrombosis & $3(7.7)$ \\
\hline \multicolumn{2}{|l|}{ Major vascular territories - $\mathrm{n}(\%)$} \\
\hline MCA & $21(53.8)$ \\
\hline $\mathrm{IPH}$ & $7(17.9)$ \\
\hline PCA & $4(10.3)$ \\
\hline Superior sagittal VST & $2(5.1)$ \\
\hline Others* & $5(12.8)$ \\
\hline \multicolumn{2}{|l|}{ Age of the CVA - n (\%) } \\
\hline Neonatal & $17(43.6)$ \\
\hline Time of the CVA $>29$ days of life & $22(56.4)$ \\
\hline \multicolumn{2}{|l|}{ Main findings of the neurologic exam - $n(\%)$} \\
\hline Right hemiparesis & $13(33.3)$ \\
\hline Left hemiparesis & $11(28.2)$ \\
\hline No motor change & $9(23.1)$ \\
\hline Others** & $6(15.4)$ \\
\hline
\end{tabular}

CVA: cerebral vascular accident; md: median; $n$ : number; MCA: middle cerebral artery; IPH: intraparenchymal hemorrhage; PCA: posterior cerebral artery; VST: venous sinus thrombosis; * cerebellar $(n=1)$, subarachnoid $(n=1)$, internal carotid artery $(n=1)$, anterior cerebral artery $(n=1)$, * cerebellar $(n=1)$, subarachnoid $(n=1)$, internal carotid artery $(n=1)$, anterior cerebral artery $(n=1)$,
straight sinus thrombosis $(n=1) ;{ }^{*}$ tetraparesis $(n=2)$, right lower limb monoparesis $(n=1)$, left upper limb monoparesis $(n=1)$, no clinical data $(n=2)$. 
Table 3. Quality of life score Pediatric Quality of Life Inventory (PedsQL $\left.{ }^{\mathrm{TM}} 4.0\right)$, according to group $(n=78)$

\begin{tabular}{|c|c|c|c|c|}
\hline Variables & $\begin{array}{c}\text { CVA } \\
(n=39)\end{array}$ & $\begin{array}{l}\text { Control } \\
(n=39)\end{array}$ & p & $\mathbf{p}_{\text {adjusted }}{ }^{*}$ TEP \\
\hline \multicolumn{5}{|l|}{ PedsQL ${ }^{\text {TM }} 4.0$ guardians } \\
\hline Functional capacity & $72.0 \pm 19.6$ & $88.6 \pm 16.7$ & $<0.001$ & 0.0280 .92 \\
\hline Emotional aspects & $68.2 \pm 17.6$ & $65.9 \pm 21.9$ & 0.609 & 0.7470 .12 \\
\hline Social aspects & $72.7 \pm 25.5$ & $84.9 \pm 16.9$ & 0.015 & 0.5660 .57 \\
\hline School-related aspects & $63.0 \pm 20.4$ & $72.2 \pm 20.1$ & 0.062 & 0.2240 .46 \\
\hline \multicolumn{5}{|l|}{ PedsQL'TM 4.0 children } \\
\hline Functional capacity & $77.7 \pm 16.2$ & $88.1 \pm 11.7$ & 0.004 & 0.0960 .74 \\
\hline Emotional aspects & $64.4 \pm 21.9$ & $66.2 \pm 19.2$ & 0.721 & 0.2360 .09 \\
\hline Social aspects & $78.3 \pm 21.7$ & $84.2 \pm 12.6$ & 0.182 & 0.8420 .33 \\
\hline School-related aspects & $61.1 \pm 21.3$ & $73.5 \pm 17.2$ & 0.013 & 0.0550 .64 \\
\hline
\end{tabular}

CVA: cerebral vascular accident; n: number; TEP: effect size * adjusted by the mother's and father's education level, mother's ethnicity, type of school, age when first attending school, income, and gestational age by the Analysis of Covariance (Ancova).

The variables age when first attending school and sex showed a significant and negative effect on the outcome of the school-related aspects of PedsQL ${ }^{\mathrm{TM}} 4.0$ in the perception of the children/adolescents (Table 4), i.e., they thought that they went late to school and the boys felt more limited when compared to the CG. The remaining variables of Table 4 did not present a significant difference.

Table 4. Multivariate linear regression analysis to assess factors associated with QoL

\begin{tabular}{|c|c|c|c|}
\hline Variables & b $(95 \% \mathrm{Cl})$ & $\mathbf{p}^{*}$ & $\mathbf{R}^{2}$ \\
\hline Emotional aspects - guardians & & & $29.0 \%$ \\
\hline Father's education level (years) & $2.20(0.04$ to 4.35$)$ & 0.046 & \\
\hline Child's age (years) & $1.54(-1,58$ to 4.66$)$ & 0.319 & \\
\hline Child's education level (years) & $-3.35(-7.43$ to 0.72$)$ & 0.102 & \\
\hline Social aspects - guardians & & & $54.1 \%$ \\
\hline Father's age & $-0.78(-1.60$ to 0.04$)$ & 0.060 & \\
\hline Child's education level & $-2.42(-5.16$ to 0.32$)$ & 0.080 & \\
\hline Gestational age & $2.24(-0.34$ to 4.82$)$ & 0.086 & \\
\hline School-related aspects - guardians & & & $45.9 \%$ \\
\hline Mother's education level & $0.46(-2.12$ to 3.03$)$ & 0.717 & \\
\hline Father's education level & $0.95(-1.70$ to 3.60$)$ & 0.468 & \\
\hline Child's age & $-1.54(-3.04$ to -0.05$)$ & 0.044 & \\
\hline Income & $0.00(-0.01$ to 0.01$)$ & 0.805 & \\
\hline Age of the CVA & $-0.13(-0.31$ to 0.06$)$ & 0.162 & \\
\hline Time of the CVA $>29$ days of life & $-20.9(-34.2$ to -7.57$)$ & 0.003 & \\
\hline School-related aspects - child & & & $38.9 \%$ \\
\hline Mother's education level & $1.31(-0.82$ to 3.43$)$ & 0.218 & \\
\hline Age of the CVA & $0.00(-0.19$ to 0.19$)$ & 0.986 & \\
\hline Age when first attending school & $-0.33(-0.60$ to -0.07$)$ & 0.016 & \\
\hline Male sex & $-19.2(-32.2 \mathrm{a}-6.2)$ & 0.005 & \\
\hline
\end{tabular}

QoL: quality of life; Cl: confidence interval; CVA: cerebral vascular accident; b: angular coefficient (measures the effect of each variable for the outcome); $\mathrm{R}^{2}$ : determination coefficient (indicates the explanation percentage of the variables present in the model regarding the outcome); ${ }^{*}$ Student's $t$ test for the angular coefficient. 


\section{DISCUSSION}

The stroke is one of the important causes of morbidity and mortality in the pediatric population due to its sequelae. Therefore, it is essential to analyze how these sequelae interfere on the impact of quality of life in the perception of guardians and children/adolescents. This perception must be aligned for the child/adolescent to have a better quality of life in the biopsychosocial aspect.

The main findings in this study concerning the profile of the participants of the CVAG is that the median age of diagnosis of the stroke was seven months. We believe that this diagnosis happens in this third quarter because it is when the parents and people closest to the baby observe that he/she is not performing tasks that other babies with the same age already perform, such as: reaching, holding and handling toys , sitting without support, performing lateral and forward protection reactions, performing anterior and lateral movements with the torso, crawling (which allows the baby to acquire depth, distance, and size perception), and moving with support (which require the upper limbs to keep the balance $)^{18}$.

An interesting data in this study were the findings concerning the sex, with greater predominance of girls. In the literature, the male sex has a large predominance in the target audience of pediatric $\mathrm{CVA}^{19}$. The exact mechanisms on interactions between sex and hormonal factors for strokes in adults, children and newborns are not yet understood, but boys and men have a higher incidence during most of their lives ${ }^{20,21}$. The study by Ghotra et al. ${ }^{7}$ corroborates our study, as it also obtained more girls with pediatric stroke, but it did not explain the reasons for this finding. Unfortunately, this item was not researched in detail concerning QoL. For further research, we suggest the use of the PedsQL ${ }^{\mathrm{TM}} 4.0$ instrument to compare the sexes throughout various age groups.

Regarding the type of CVA, we observed in this study a prevalence of ischemic stroke. The results are in accordance with the reference data, showing children with CVA of the ischemic type ${ }^{22}$. Other findings that also corroborate with the literature refer to the main vascular territory (the middle cerebral artery is the artery which is more prone to injury due to its anatomy and thinner walls) ${ }^{23}$, the age at which children presented the time of the CVA ( $>29$ days of life $)^{24}$, and hemiparesis ${ }^{25}$.

To investigate the quality of life, some studies ${ }^{26}$ used questionnaires directed to children and/or their guardians. It is important to note that these questionnaires specifically intend to know the perception of each of them (guardians and/or children/adolescents). They include different areas (functional, emotional, and school) and how they would affect the life of this target audience.

This study opted to use the PedsQL ${ }^{\mathrm{TM}} 4.0$, an instrument aligned with biopsychosocial aspects and with the ICF. We believe that not only body-related concerns influence the QoL of children/adolescents. We understand that their relationship with their families and with society is a means of facilitating or hindering QoL. We also understand that the alignment of the views of the child/adolescent with their guardians is extremely important so that they can be united in a common goal, preparing the child/adolescent for life. If one of them is at odds with the other, several barriers can occur, worsening the QoL.

For the guardians, the PedsQL ${ }^{\mathrm{TM}} 4.0$ identified a significant difference in the functional capacity score, which involved walking and tasks performed with the upper limbs. For the guardians from the CVAG, the children/adolescents presented inferiority in this score when compared to the children/adolescents from the CG, even after the adjustments by confounders. The guardians understand that these changes of functional capacity can lead to limitations in their activities, which, consequently, can affect their self-confidence ${ }^{27}$.

They notice that the walking of most children/ adolescents shall be described as normal in the long run. However, some require bracing to walk more efficiently ${ }^{28}$. The tasks that require the hand, for example, although presenting restrictions in the studies, are of significant concern for guardians when their children two-hand tasks refer particularly to eating and dressing ${ }^{29}$. It is interesting to note that children/adolescents from the CVAG did not identify this problem when compared to the CG. Children/adolescents can talk to their guardians about it so that they realize that the child does not feel a decreased functional capacity. This would increase the children's self-esteem, because the parents would not feel pity and would invest in the possibilities the children already believe they have.

Still, in the guardians' perception, children with disabilities may show behavior problems. They recognize an inadequacy of the children's behavior because parents adopt an educational practice based on permittivity and overprotection and, consequently, do not allow their children to have the necessary space for learning and making mistakes to handle themselves ${ }^{28}$. Parents should not make any distinction regarding the education of children with disabilities and typical children. 
In the children/adolescents' perception, the PedsQL ${ }^{\mathrm{TM}}$ 4.0 did not observe any significant difference between the groups. However, it is possible to observe that the values of all aspects were lower when compared to the $\mathrm{CG}$, mainly regarding functional capacity and social and school-related aspects. What draws attention is that the emotional aspects were very close to the CG. However, in previous studies, children with disabilities, due to the conditions of their pathology, are more vulnerable to bullying. In addition to its impact on health and psychological aspects, bullying is a predictor of low selfesteem, anxiety, depression, and lower $\mathrm{QoL}^{30}$. Children with disabilities are three times more likely to suffer social exclusion as they are less popular, have less friends, and participate less often as members of a subgroup ${ }^{31}$. It is essential to carry out studies to investigate the important factors of how children with disabilities are excluded, as well as planning disability awareness programs and antibullying interventions ${ }^{32}$.

What can explain the responses of children regarding the emotional aspects cited being close between CVAG and $\mathrm{CG}$ was demonstrated by the multivariate linear regression analysis, which found that the father's education level in the guardians' questionnaire Peds $\mathrm{QL}^{\mathrm{TM}} 4.0 \mathrm{kept}$ the positive effect on the children's emotional aspects. The higher the level of the parents' education, the better are the conditions of employment and family income, and better will be the quality and quantity of appropriate stimuli to development. In fact, the guardians' education level has shown to be a protection factor ${ }^{33}$. The guardians having a higher education level allows quality stimulation of the children, even if sometimes the time dedicated to this interaction is smaller. It can be said that it is a variable of persistent impact on the child's development, influencing care, organization, and motor opportunities available ${ }^{34}$.

Still regarding the multivariate linear regression analysis, concerning the social aspects, there was no significant difference, possibly due to the small sample size, different from the literature, which reports that children/ adolescents who have suffered strokes have difficulty with emotional processing and also have a below-average performance in autonomy and social acceptance aspects. Many aspects of the disease generate stress, anguish, and fear, and to some extent overwhelm not only the child, but also the family, which consequently hinders the social and emotional well-being ${ }^{35}$.

Another key factor in the multivariate linear regression analysis regarding the guardians' perception were the variables age of the child and the time of the
CVA $>29$ days of life. The parents understand that the disability is more noticeable as the child gets older, mainly regarding school performance ${ }^{36}$. As the child matures, and perceptual and motor area and functions become more functional and capable for the performance of increasingly complex skills. Therefore, to effective learn, maturing and integrating the various brain areas involved in the process are essential ${ }^{37}$. The earlier the child starts his/her learning process, the better would be the school results.

In the multivariate linear regression analysis according to the children/adolescents' account, the disease usually comes with costly particularities. Their perception is that the disease influences their insertion in school and has an impact on their academic achievement. The children from the CVAG went to school for the first time later and their performance presented significant negative effect. The child's school QoL, among other aspects, is directly related to their emotional and physical well-being. These are the factors that will influence the child's attendance to school, his/her state of mind, and, consequently, the performance of inherent activities ${ }^{38}$.

In the children/adolescents' perception, the boys who replied to the questionnaire feel more difficulty to learn than the girls. The literature has indicated that boys with any type of disability often present more learning and attention disorders than girls. In addition, the maturing of girls' brains happens before than that of boys. These late maturing regions of boys present an accelerated thinning during adolescence, corresponding to networks that underlie the cognitive functions ${ }^{39}$.

This study was important for being a pioneer in the area of physical therapy concerning pediatric stroke and QoL in Brazil. Another important aspect was that it noticed that the evaluation of QoL of Brazilian children/ adolescents who suffered a stroke was different when comparing the guardians' and the children accounts. The parents perceived a greater functional impairment than their children. Another relevant finding on the guardians' account is that the father's educational level positively influenced the child's emotional aspects. As for the children who first attended school late, they believe that they are hindered regarding school performance. The boys consider themselves to have a limited learning ability.

The study's limitation include sample size and the use of a generic QoL scale in the research, since a validated scale translated to Portuguese aimed specifically for stroke in this age group does not exist. Another limitation that must be highlighted is that we did not 
evaluate the language, cognitive, motor, behavioral, and socioadaptive aspects.

It should be noted that, due to the assertive diagnosis of pediatric stroke, more research are needed in Brazil so that tools are created to improve the QoL of this population. The findings of this research are an invitation to physical therapists to think of evaluative and intervention strategies for children with stroke, as they are in the peak of motor and psychosocial learning. We suggest the development of public policies favoring the health promotion of these children. The physical therapist must participate in an interdisciplinary team and, along with this team, propose solutions to the problems of this population, and offer training for guardians, as well as educational workshops for children and school environments, in line with the biopsychosocial factors. These actions must be initiated as soon as possible.

\section{ACKNOWLEDGMENTS}

To Conselho Nacional de Desenvolvimento Cientifico e Tecnológico $(\mathrm{CNPq})$ for the financial assistance that made this work possible.

\section{REFERENCES}

1. Patra C, Sarkar S, Guha D, Dasgupta MK. Clinico-etiological profile of childhood stroke in a Tertiary Care Hospital in Eastern India. J Neurosci Rural Pract. 2015;6(4):515-9. doi:10.4103/0976-3147.165414

2. Mandalenakis Z, Rosengren A, Lappas G, Eriksson P, Hansson $\mathrm{PO}$, Dellborg M. Ischemic stroke in children and young adults with congenital heart disease. J Am Heart Assoc. 2016;5(2). pii: e003071. doi:10.1161/JAHA.115.003071

3. Miniño AM, XU J, Kochanek KD. Deaths: preliminary data for 2008. Natl Vital Stat Rep. 2010;59(2):1-52.

4. Mathias E, Sethuraman U. Ischemic stroke of the spinal cord: a pediatric emergency in an otherwise healthy child. J Emerg Med. 2016;51(1):73-6. doi:10.1016/j.jemermed.2016.03.001

5. Intercollegiate Working Party for Paediatric Stroke (IWPP). Clinical guidelines for diagnosis and management of acute stroke in childhood. London: Royal College of Physicians; 2004.

6. Statler KD, Dong L, Nielsen DM, Bratton SL. Pediatric stroke: clinical characteristics, acute care utilization patterns, and mortality. Childs Nerv Syst. 2011;27(4):565-73. doi: 10.1007/ s00381-010-1292-x

7. Ghotra SK, Johnson JA, Qiu W, Newton A, Rasmussen C, Yager JY. Age at stroke onset influences the clinical outcome and health-related quality of life in pediatric ischemic stroke survivors. Dev Med Child Neurol. 2015;57(11):1027-34. doi:10.1111/ dmcn.12870
8. Lopes MT, Ferraro AA, Koch VHK. Reliability of the Brazilian version of the PedsQL-ESDR questionnaire to evaluate quality of life of children and adolescents. J Bras Nefrol. 2015;37(2):15865. doi:10.5935/0101-2800.20150026

9. Castro SS, Castaneda L, Araújo ES, Buchalla CM. Aferição de funcionalidade em inquéritos de saúde no Brasil: discussão sobre instrumentos baseados na Classificação Internacional de Funcionalidade, Incapacidade e Saúde (CIF). Rev Bras Epidemiol. 2016;19(3):679-87. doi: 10.1590/1980-5497201600030018

10. Cumming TB, Brodtmann A, Darby D, Bernhardt J. The importance of cognition to quality of life after stroke. J Psychosom Res. 2014;77(5):374-9. doi:10.1016/j. jpsychores.2014.08.009

11. Ghotra SK, Johnson JA, Qiu W, Newton AS, Rasmussen C, Yager JY. Health-related quality of life and its determinants in paediatric arterial ischaemic stroke survivors. Arch Dis Child. 2018; pii: archdischild-2017-313334. doi: 10.1136/ archdischild-2017-313334

12. Smith SE, Vargas G, Cucchiara AJ, Zelonis SJ, Beslow LA. Hemiparesis and epilepsy are associated with worse reported health status following unilateral stroke in children. Pediatr Neurol. 2015;52(4):428-34. doi: 10.1016/j. pediatrneurol.2014.11.016

13. Klatchoian DA, Len CA, Terreri MTRA. Quality of life of children and adolescents from São Paulo: reliability and validity of the Brazilian version of the Pediatric Quality of Life Inventory ${ }^{\top M}$ version 4.0 Generic Core Scales. J Pediatr. 2008;26(3):631-6. doi: 10.1590/S0021-75572008000400005

14. Athayde F, Mancuzo EV, Corrêa RA. Influência ambiental sobre a incapacidade física: uma revisão sistemática da literatura. Ciênc Saúde Colet. 2017;22(11):3645-52. doi: 10.1590/1413-812320172211.01992017

15. Desai AD, Zhou C, Stanford S, Haaland W, Varni JW, MangioneSmith RM. Validity and responsiveness of the pediatric quality of life inventory (PedsQL) 4.0 generic core scales in the pediatric inpatient setting. JAMA Pediatr. 2014;168(12):111421. doi:10.1001/jamapediatrics.2014.1600

16. Limbers CA, Ripperger-Suhler J, Heffer RW, Varni JW. Patientreported Pediatric Quality of Life Inventory ${ }^{\top \mathrm{M}} 4.0$ Generic Core Scales in pediatric patients with Attention-Deficit/ Hyperactivity Disorder and comorbid psychiatric disorders: Feasibility, reliability and validity. Value Health. 2011;14(4):52130. doi:10.1016/j.jval.2010.10.031

17. Varni JW, Limbers CA, Neighbors K, Schulz K, Lieu JE, Heffer RW, et al. The PedsQL ${ }^{\text {TM }}$ Infant Scales: Feasibility, internal consistency reliability and validity in healthy and ill infants. Qual Life Res. 2011;20(1):45-55. doi:10.1007/s11136-010-9730-5

18. Gerzson LR, Azevedo KA, Demarco PR, Catarino BM, Palma MS, Almeida CS. O berçário da escola pública: aplicação de um programa de intervenção motora oportuna. Fisioter Bras. 2017;18(4):417-25. doi: 10.1590/1809-2950/14923223022016

19. Morgan CT, Manlhiot C, McCrindle BW, Dipchand Al. Outcome, incidence and risk factors for stroke after pediatric heart transplantation: an analysis of the International Society for Heart and Lung Transplantatiosn Registry. J Heart Lung Transplant. 2016;35(5):597-602. doi:10.1016/j.healun.2016.01.1226 
20. Turtzo LC, McCullough LD. Sex-specific responses to stroke. Future Neurol. 2010;5(1):47-59. doi: 10.2217/fnl.09.66

21. Children's Hemiplegia and Stroke Association (Chasa). Hemiplegia [homepage na internet]. [s.d.] [citado em 2018 maio 18]. Disponível em: <http://chasa.org/medical/ hemiplegia/>

22. Mallick AA, Ganesan V, Kirkham FJ, Fallon P, Hedderly T, McShane T, et al. Childhood arterial ischaemic stroke incidence, presenting features, and risk factors: a prospective populationbased study. Lancet Neurol. 2014;13(1):35-43. doi:10.1016/ S1474-4422(13)70290-4

23. Mah S, deVeber G, Wei XC, Liapounova N, Kirton A. Cerebellar atrophy in childhood arterial ischemic stroke: acute diffusion MRI biomarkers. Stroke. 2013;44(9):2468-74. doi:10.1161/ STROKEAHA.111.000744

24. Munube D, Katabira E, Ndeezi G, Joloba M, Lhatoo S, Sajatovic $M$, et al. Prevalence of stroke in children admitted with sickle cell anaemia to Mulago Hospital. BMC Neurol. 2016;16:175. doi:10.1186/s12883-016-0704-2

25. Graziano AP, Sancilio A, Bugalter M, Barbosa W, Rodríguez F, Montali C, et al. Cerebrovascular disease in childhood. Case series. Arch Argent Pediatr. 2016;114(1):e5-8. doi:10.5546/ aap.2016.e5

26. Friefeld SJ, Westmacott R, Macgregor D, Deveber GA. Predictors of quality of life in pediatric survivors of arterial ischemic stroke and cerebral sinovenous thrombosis. J Child Neurol. 2011;26(9):1186-92. doi:10.1177/0883073811408609

27. Greenham M, Gordon A, Anderson V, Mackay MT. Outcome in childhood stroke. Stroke. 2016;47(4):1159-64. doi:10.1161/ STROKEAHA.115.011622

28. Gordon AL. Functioning and disability after stroke in children: using the ICF-CY to classify health outcome and inform future clinical research priorities. Dev Med Child Neurol. 2014;56(5):434-44. doi:10.1111/dmcn.12336

29. Galvin J, Randall M, Hewish S, Rice J, MacKay MT. Family-centred outcome measurement following paediatric stroke. Aust Occup Ther J. 2010;57(3):152-8. doi:10.1111/j.1440-1630.2010.00853.x
30. Chatzitheochari S, Parsons S, Platt L. Doubly disadvantaged? Bullying experiences among disabled children and young people in England. Sociology. 2016;50(4):695-713. doi: 10.1177/0038038515574813

31. Lindsay S, McPherson AC. Experiences of social exclusion and bullying at school among children and youth with cerebral palsy. Disabil Rehabil. 2012;34(2):101-9. doi:10.3109/096382 88.2011.587086

32. Bourke S, Burgman I. Coping with bullying in Australian schools: how children with disabilities experience support from friends, parents and teachers. Disabil Soc. 2010;25(3):359-71. doi:10.1080/09687591003701264

33. Costa EF, Cavalcante LIC, Dell'aglio DD. Language development profile of children in Belem, according to Denver developmental screening test. Rev CEFAC. 2015;17(4):1090102. doi: 10.1590/1982-0216201517418514

34. Pereira KRG, Saccani R, Valentini NC. Cognition and environment are predictors of infants' motor development over time. Fisioter Pesqui. 2016;23(1):59-67. doi: 10.1590/1809-2950/14685223012016

35. Ball AJ, Steinberg GK, Elbers J. Quality of life in pediatric moyamoya disease. Pediatr Neurol. 2016;63:60-5. doi:10.1016/j. pediatrneurol.2016.06.012

36. Mallick AA, Ganesan V, O'Callaghan FJ. Mortality from childhood stroke in England and Wales, 1921-2000. Arch Dis Child. 2010;95(1):12-9. doi:10.1136/adc.2008.156109

37. Dennis M, Spiegler BJ, Juranek JJ, Bigler ED, Snead OC, Fletcher JM. Age, plasticity, and homeostasis in childhood brain disorders. Neurosci Biobehav Rev. 2013;37(10Pt2):276073. doi:10.1016/j.neubiorev.2013.09.010

38. Holanda ER, Collet N. The difficulties of educating children with chronic illness in the hospital context. Rev Esc Enferm USP. 2011;45(2):381-9. doi: 10.1590/S0080-62342011000200012

39. Mutlu AK, Schneider M, Debbané M, Badoud D, Eliez S, Schaer M. Sex differences in thickness, and folding developments throughout the cortex. Neuroimage. 2013;82:200-7. doi: 10.1016/j.neuroimage.2013.05.076 